\title{
Management under Crisis Conditions - the Impact of the COVID-19 Pandemic on the Formation of Respondents' Opinions within the e-commerce Market, in Poland
}

\author{
Justyna Lukomska-Szarek, Anna Martynko, Żaneta Warzecha \\ Faculty of Management, Czestochowa University of Technology, Al. Armii \\ Krajowej 19 B, 42-201 Częstochowa, Poland; j.lukomska-szarek@pcz.pl, \\ anna.martynko@pcz.pl, zaneta.warzecha@pcz.pl
}

\begin{abstract}
The outbreak of the COVID-19 pandemic was an unexpected phenomenon that triggered a multitude of changes within various aspects of socioeconomic functioning. The ongoing pandemic is a threat to health and life. What is more, it negatively impacts the economy and alters social and consumer behavior. These transformations are visible in relation to commercial activities, which have largely been transferred to the online zone. The aim of this paper was to verify the adopted hypotheses whether the pandemic has a statistically significant impact on the opinions of respondents aged $45+$ about the e-commerce market. Two statistical methods, such as, chi-squared test of independence and Wilcoxon pairwise rank test were used to verify the accepted hypotheses. Based on the statistical analysis, it has been proven that the pandemic had a significant impact on the opinions of the respondents concerning online safety, unlimited availability of the offered products and the need for further improvements in current technologies. During the pandemic, a correlation has also been established between the gender of the respondents and their opinions on online shopping as a better alternative to brick-and-mortar shopping. Moreover, a relationship was demonstrated between gender and the opinions of the respondents, that further development of new information and communication technologies is necessary. The study showed that the COVID-19 pandemic statistically influenced differences in the distribution of variables, in the area of respondents' behavior, within the e-commerce market.
\end{abstract}

Keywords: crisis management; e-commerce; COVID-19; consumer; consumer behavior

\section{Introduction}

The outbreak of COVID-19 pandemic can be identified as an unexpected and crisis situation, which in the initial stage stopped the activities of companies in many industries, thus, disrupting the smoothly functioning management mechanisms. In addition to the economic and financial impact, the pandemic has undoubtedly 
affected customer behavior in the area of trade, which has largely moved to the Internet. The basis of this study is a review of available literature sources, industry reports and the results of empirical studies conducted using the CAWI method. The study, based on my empirical research, pays special attention to the change in respondents' opinions about the e-commerce market, before and during the pandemic. The opinions of respondents aged $45+$ on e-commerce before and during the COVID-19 pandemic were analyzed. The aim of the paper is to verify the accepted hypotheses of whether or not the COVID-19 pandemic triggered a statistically significant impact on respondents' opinions, concerning the e-commerce market. Therefore, two statistical methods, the chi-squared test of independence and the Wilcoxon pairwise rank order test, were used.

\section{Theoretical Background}

The success of an enterprise is inextricably linked to the quality of management, which is associated with the ability to direct processes, information or resources in a given entity to achieve the adopted objectives in an effective manner. According to Peter Drucker, management designates the social and economic development that results from it [1].

Management is primarily about people and is deeply embedded in culture [2]. It includes functions such as planning, organizing, motivating and controlling [3]. Planning is the determination of an organization's goals and how to achieve them. Organizing can be defined as a managerial activity directed at determining the best method of classifying the organization's activities and resources. The last two functions refer to regulating the behavior of employees and observing the progress of the organization in achieving its objectives [4]. Some authors recognize that the concept of management is so complex that its explanation is not possible through a single definition [5]. However, the fact that in its essence it focuses on the human factor is undeniable, and so the people employed, while the final result of the taken actions is to be customer satisfaction. Yet, wrong decisions can have the opposite effect [6].

When crisis situations arise, the management of any entity, including those operating in the field of e-commerce, is hampered and made a subject to numerous negative incentives. The very concept of crisis is defined as an unintended process containing a course of events taking place at a specific time, which disrupts the balance of the company and the environment and affects the viability of the organization. Such a situation influences the necessity of making difficult and, most of all, risky decisions by owners, managers or executives, concerning the financial, organizational or personal sphere. Crisis phenomena may also be a threat to the realization of company's goals or even lead to its collapse. Identification of customers' needs and motivations has a significant impact on managing a company 
during a crisis and a possibility of taking specific actions to reduce its negative consequences [7]. In the process of managing a crisis situation, a fundamental role is played by the management staff, who take such decisions [8]. Crisis on the basis of management science has a pejorative character and is an event of low probability of occurrence and high impact [9]. The causes of occurrence and its results are usually ambiguous [10]. A crisis can also threaten the safety and even the lives of employees, customers, or the community at large. One consequence of the occurrence of such a phenomenon may be a breakdown of public trust in organizations, which would affect their reputation. The consequences of a crisis can be identified in many ways, ranging from physical, financial or psychological damage, through the depletion of a company's financial resources to its collapse in the end [11]. A crisis is a very difficult occurrence for a company also because of the speed of its development and the fact that its end is extremely hard to define [12]. In addition to the effects of pejorative overtones, it can be indicated that the crisis situation can even lead to renewal of the company, through the forced need to learn [13]. The crisis is then treated as a stage, that enables a new life or the introduction of new technology [14].

The modern world is dominated by information and communication technologies [14]. Technological progress as an expression of widespread access to digital services and mobile devices affects the functioning of users around the world [16]. The driving force behind these transformations in the digital world is considered to be the e-commerce market [17]. Electronic commerce, or e-commerce is an issue whose origins date back to the 1990s, when there was a commercial development of the Internet, with which it is inextricably linked [18]. E-commerce, e-trade or electronic commerce are sometimes treated as the same concept. Despite the multitude of scientific publications, currently there is no uniform definition, due to the continuous technological progress and different emphasis on the discussed issue. Therefore, as noted by M. Lewicki, defining e-commerce depends mainly on the context in which it is used [18]. The Central Statistical Office defines the e-commerce market as: "Transactions conducted over networks, based on the IP protocol and over other computer networks."[20]. In a similar vein, the e-commerce market is defined by other authors identifying it with the type of transactions carried out through Internet technologies. [21] [22]. The OECD, in turn, identifies the concept of e-commerce as an order for the purchase/sale of a service or good, placed using a computer network, the recipients of which may be both private and public, while the distribution and payment for the service received may take the traditional form [23]. The term e-commerce can also refer to the phenomenon of using the global network for activities related to the service, purchase, or sale of the offered products [24]. However, as noted by the WTO [25], e-commerce is not only about financial transactions, because the term also defines such online activities as marketing, data exchange, and sales support. Although the e-commerce market consists of many individual segments, the most popular activity manifests itself through buying or selling activities [26]. 
The current understanding of e-commerce is inextricably linked to the Internet. The implementation of electronic data interchange (EDI) is considered to be the beginning of e-commerce. Demand, as a result of the expanding number of entertainment or information browsers, contributed to the use of the Internet by households. The gradual expansion of e-commerce to include a range of newer and newer businesses offering their services and products through the use of the Internet contributes to the ever-expanding e-business [27].

Nowadays, e-commerce is considered to be one of the key segments of the economy that leaves its mark on the functioning of entire societies. Hence, e-commerce can be seen as an obligatory enabling element in today's economy [28]. Therefore, it seems reasonable to discuss the advantages and disadvantages of the e-commerce market. Advantages can be considered from the perspective of the various stakeholders i.e. customers, businesses and society. The disadvantages can be classified into technical and non-technical disadvantages as shown in Fig. 1.

Both in the area of traditional trade and e-commerce, the key role and function is played by the consumer. According to Kowalik, a consumer is a natural person who conducts a legal act with the entrepreneur, which is not directly related to his business or professional activity. Consumption is based on the use of material and spiritual goods, in such a way as to meet specific needs [29]. Thus, consumers' needs are the motivation for a purchasing process [30]. Buyers decide to choose the most advantageous offer for themselves, and their behavior is a consequence of innate and acquired needs and aspirations, the satisfaction of which is possible through a combination of conscious and unconscious processes and emotional stimuli [31].

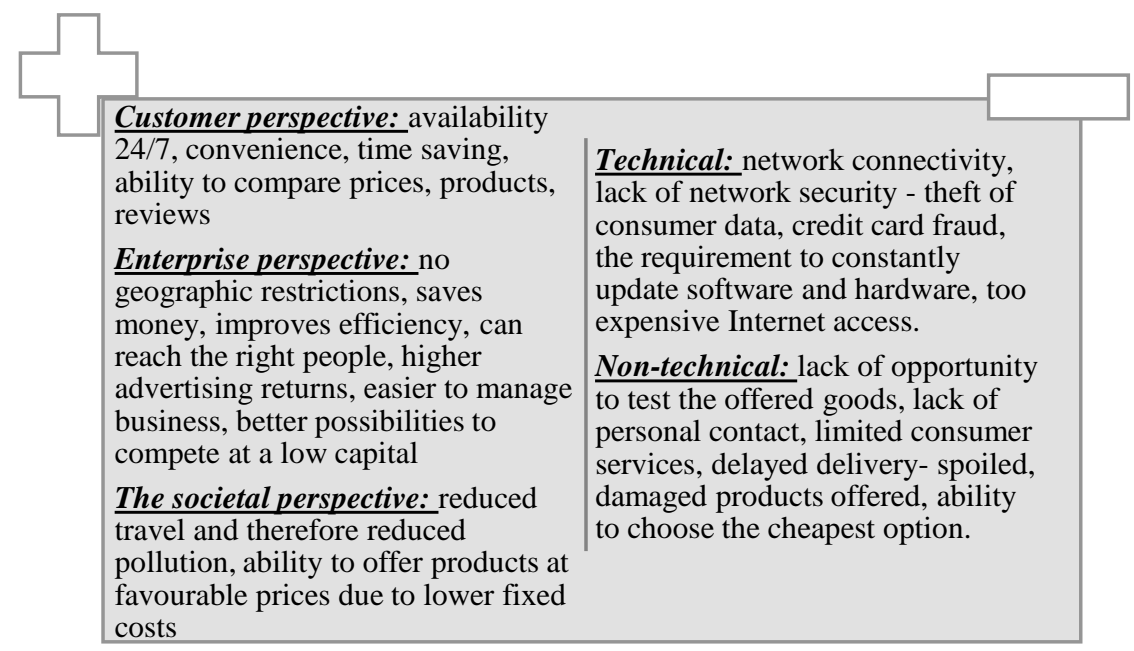

Figure 1

Advantages and disadvantages of e-commerce

Source: Own study based on [32] 
One product should satisfy many needs, while one need can be satisfied by a variety of offers. The foundation of marketing decisions is to know the reasons why consumers choose a particular product, as well as to acquire knowledge about purchasing behaviors and the directions of their changes [30].

In the literature, consumer behavior is defined as actions taken by individuals who make subjective choices regarding the purchase of goods and services, as well as ways of using the goods they own or getting rid of used goods [33]. According to another definition, these behaviors are defined as activities related to: seeking, acquiring, using, and evaluating goods and services to satisfy consumer needs [34].

Consumer behavior, through its interdisciplinary nature, can be considered in various aspects. The consumer's decision to purchase a product depends on many factors, including: economic, psychological, social, as well as the components of the marketing mix. Companies care about matching their offers to consumer needs, as well as the possibilities and skills to create these needs [35].

Currently, consumers are more and more frequently and willingly making purchases via the Internet. The behavior of e-commerce customers and customers of brickand-mortar shops show significant differences. Online shoppers tend to have more products, services, and information at their disposal than during traditional in-store shopping. However, the lack of a direct seller-customer relationship when shopping online limits the elicitation of desired purchasing reactions [36].

Consumer behavior can be divided into: rational and irrational. Rational behavior is manifested when the consumer, receiving a certain income, purchases only such quantities of goods that cause him the greatest satisfaction. Irrational behavior of buyers can be found when they act internally inconsistent, contrary to their own interests, and their actions are dictated by imitation, impulse, snobbery or motives that may lie in their consciousness [37].

The shopping behavior of online and in-store consumers is determined by various factors. A breakdown of factors and their examples are presented in Fig. 2.

External (exogenous) factors

Internal (endogenous) factors

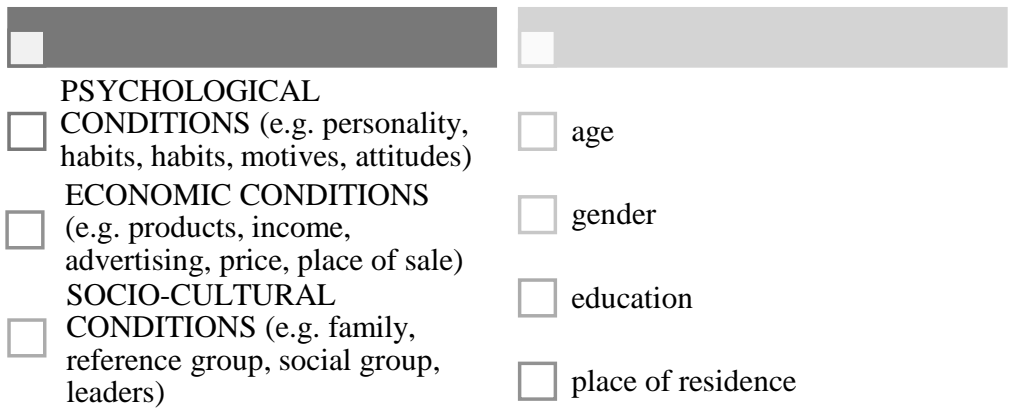

Figure 2

Determinants of the purchasing behavior of consumers

Source: own study based on [38] 
In the literature we can come across different models of customer behavior in the e-commerce market. According to one of them, consumers see a product for the first time in stationary stores, then they look for additional information about it on the Internet, and eventually they make a purchase. According to another model, consumers first obtain information about a product in online stores, and then decide to buy it in a stationary store after physical contact with the product. These models are often identified with the age of the buyers, the first of which is attributed to young people [39].

All consumers are unique, so the influence of individual factors can determine their behavior in different ways. The most influential factor is considered to be the economic criterion, which is expressed by purchasing goods at the lowest possible price [40]. Motivation, the environment and political factors have a significant influence on the attitude of consumers to e-commerce [41]. The evolving environment and advancing technological and information development create new opportunities and solutions. The influence of external factors can have both positive and negative effects, and it is not always possible to control them. Consumers most often adapt to the changing environment, as exemplified by the outbreak of the COVID-19 pandemic. According to the latest research, the COVID-19 pandemic contributed to a change in consumer purchasing behavior, which was visible in all e-commerce subsectors. The interest in e-shopping increased in relation to sports equipment, retail services, cosmetic products, and financial services by $23.6 \%$, $7.0 \%, 3.7 \%$ and $1.8 \%$, respectively [41]. The change in consumer behavior resulted not only from the COVID-19 pandemic itself but also from the government restrictions. Consumers, regardless of their age group, now buy online more often [43].

According to the OECD report "E-commerce in the times of COVID-19", e-commerce is the fastest-growing segment of commerce in recent years. 5 years ago, the global market was worth about $\$ 1$ trillion, but currently, it is over $\$ 3$ trillion. The annual growth of the e-commerce market is around 20\%.[44].

According to the report "E-commerce i fintechy. System naczyń połączonych "(data: Retailx), the value of the Polish e-commerce market was EUR 12 billion in 2019. In Europe, the UK has the largest online shopping market - EUR 200 billion in 2019, followed by Germany (EUR 105 billion), and France (EUR 94 billion). The Polish e-commerce market is growing dynamically, both in terms of the value of products sold and the number of online stores. At the same time, the contribution of online purchases in total retail sales is growing in each segment. [45].

Summing up, it should be noted that the world is currently dominated by ICT. Based on the literature review, it was remarked that the outbreak of the COVID-19 pandemic significantly contributed to the development of the e-commerce market in Poland and around the world. This segment of the economy has left a significant mark on the functioning of society as a whole. The pandemic also affected the behavior of consumers, who are buying more and more frequently and willingly via the Internet. 


\section{Research Methodology}

According to the data collected by the Central Statistical Office [46] over the years the percentage of people using the web for activities such as ordering or buying has been systematically increasing. In 2020 in Poland about $61 \%$ of the population, which is about 17.6 million people, will make purchases on the e-commerce market. Undoubtedly, the factor that significantly affected the functioning of the entire economy was the outbreak of the COVID-19 pandemic. The lockdown introduced in March 2020 and the fear of contagion significantly contributed to the shift of activity to the web. This was reflected both in terms of various leisure activities to daily life activities such as shopping, visiting the office, bank or e-healthcare. According to the CBOS report of July 2019, the main determinant of online activity is age [47]. In the group of older people i.e. over 55 years of age, education is also important. According to the above mentioned publication, 3 out of 4 oldest respondents did not use the Internet. Therefore, the aim of this study was to determine the behavior of consumers in the 45+ group in the e-commerce market. The age of the respondents was selected due to the risk group (older people - more vulnerable to infection) and due to low online activity before the pandemic. The research design was as follows, as shown in Fig. 3.

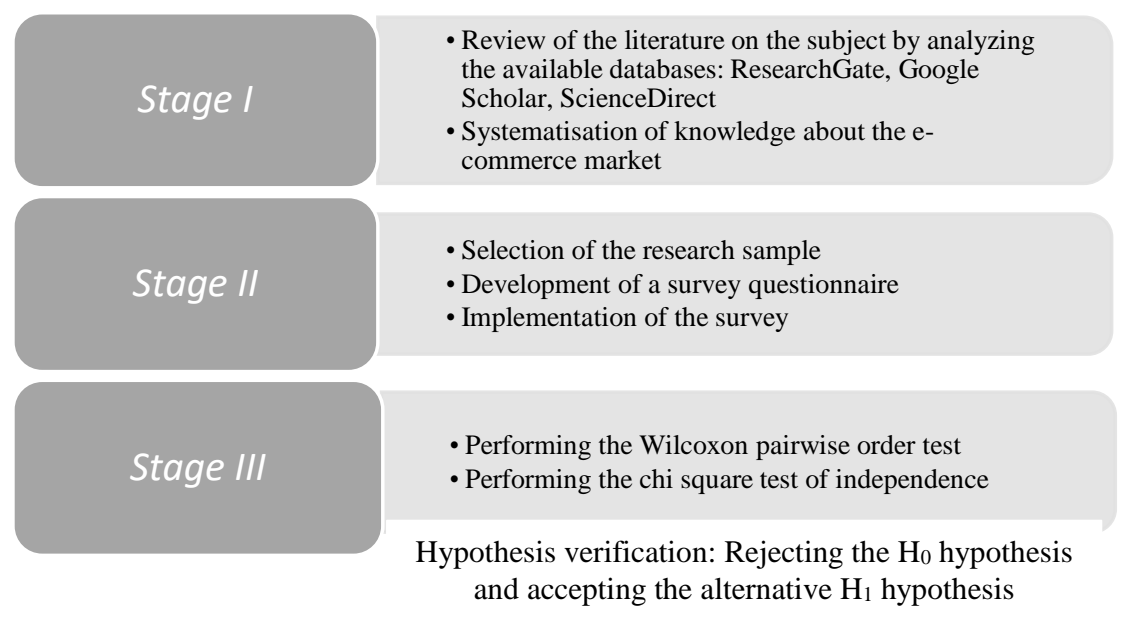

Figure 3

Research process stages

Source: own research

The SARS-COV 2 pandemic is characterized by many changes of a socio-economic nature. In addition to the real threat to life and health, the COVID-19 pandemic also entails different social and consumer behavior. These changes are particularly evident in the area of commercial activities. 
Therefore, it is considered reasonable to verify the chosen research question whether COVID-19 pandemic affects consumer behavior in e-commerce market. For this purpose, the following hypotheses were adopted:

Ho: $\quad \mathrm{F}_{1}=\mathrm{F}_{2}$ COVID-19 pandemic did not affect the statistically significant differences in the distributions of variables in the area of consumer behavior in the group of respondents over 45 years old in the e-commerce market.

$\mathbf{H}_{1}: \quad \mathrm{F}_{1} \neq \mathrm{F}_{2}$ the COVID-19 pandemic affected statistically significant differences in the distributions of variables in the area of consumer behavior among respondents over 45 years old in the e-commerce marketplace.

The questionnaire included questions to assess consumer behavior and motivations before and during the pandemic. The questionnaire consisted of both qualitative and quantitative questions and a metric. The survey was implemented with a nonrandom sample. Responses were obtained by posting the survey on https://swpanel.pl/. The survey was completed by 437 people, of which people over the age of 45 accounted for approximately $34 \%$. More than half of the people in the $45+$ sample were women. The majority of the surveyed sample consisted of people living in cities between 20-100 thousand, which is 33\%, and respondents living in cities with more than 100 thousand inhabitants. The majority of the research group consisted of economically active respondents with secondary and higher education.

A five-point Likert scale, bounded by phrases ranging from strongly agree (5) to strongly disagree (1), was used to determine differences between the pre-pandemic and during-pandemic states. In order to determine whether there were significant differences in respondents' opinions about the e-commerce market before and during the pandemic, a Wilcoxon pairwise rank order test was performed due to the fact that two dependent groups could be paired before and after the experiment. Calculations were performed using Statistica software. In order to verify whether the respondents' opinions about payment and data security during online shopping, online shopping as a better alternative to stationary shopping, and the need for further development of new information and communication technologies are statistically significantly dependent on gender, place of residence, age, education, or average monthly net income, a chi square test of independence was performed. Calculations were performed using Microsoft Excel. 


\section{Results and Discussion}

\subsection{Wilcoxon Pair Order Test}

To verify the hypotheses, the Wilcoxon pairwise rank order test was performed. Test probability level values of $p \leqslant 0.05$ were obtained, so there are grounds to reject the null hypothesis $\mathrm{H}_{0}$ and accept the alternative hypothesis $\mathrm{H}_{1}$. Thus, it should be concluded that the opinions of the respondents before and during the pandemic are statistically significantly different from each other.

Table 1

Wilcoxon pair order test

\begin{tabular}{|l|c|c|c|c|}
\hline \multicolumn{1}{|c|}{ Variables } & $\mathrm{N}$ & $\mathrm{T}$ & $\mathrm{Z}$ & $\mathrm{P}$ \\
\hline $\begin{array}{l}\text { respondents' views on payment and data security } \\
\text { during online shopping before \& during } \\
\text { pandemic }\end{array}$ & 60 & 238.5000 & 4.980124 & 0.000001 \\
\hline $\begin{array}{l}\text { survey respondents' opinions on: "online } \\
\text { shopping is a better alternative to stationary } \\
\text { shopping" before pandemic \& during pandemic }\end{array}$ & 55 & 322.5000 & 3.749400 & 0.000177 \\
\hline $\begin{array}{l}\text { survey respondents' opinions on: "further } \\
\text { development of new information and } \\
\text { communication technologies is necessary" before } \\
\text { \& during the pandemic }\end{array}$ & 44 & 289.0000 & 2.404060 & 0.016215 \\
\hline
\end{tabular}

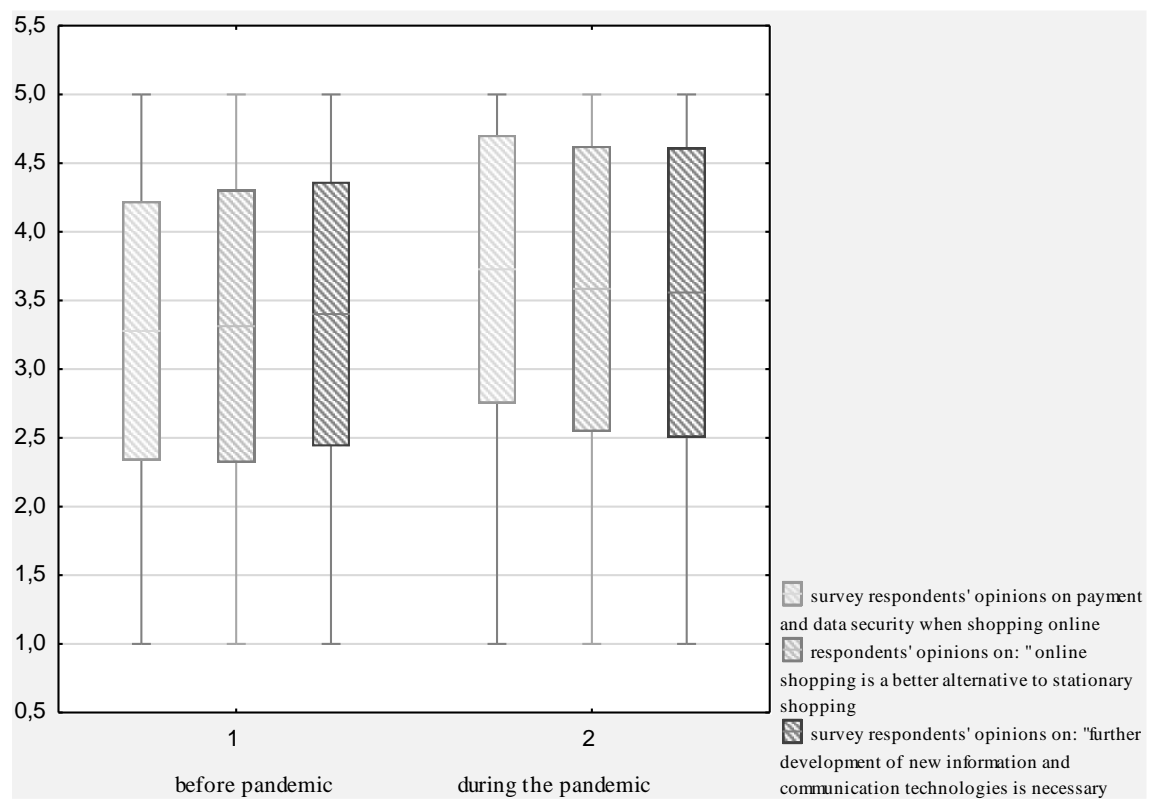

Figure 4

Wilcoxon pair order test

Source: Own research 
The results show that the pandemic had a significant impact on the respondents' opinions on online safety, unlimited availability of offered products and the need for further improvement of current technologies. The results of the Wilcoxon rank order test are presented in Fig. 4.

\subsection{Chi Squared Independence Test $\left(\chi^{2}\right)$}

The results of the chi square $\left(\chi^{2}\right)$ independence test conducted are shown in Tab. 2 .

The computational process involved several steps. The first step was the calculation of theoretical counts assuming that the variables are independent. The next step was the calculation based on the following formula:

$$
x^{2}=\sum_{i=1}^{k} \sum_{j=1}^{S} \frac{\left(n_{i j}-n_{i j}^{\prime}\right)^{2}}{n_{i j}^{\prime}}
$$

Where:

$$
\begin{aligned}
& \mathrm{n}_{\mathrm{ij}} \text { - observed counts } \\
& \mathrm{n}^{\prime}{ }_{\mathrm{ij}} \text { - theoretical values }
\end{aligned}
$$

The critical value tables of the chi-squared distribution were then read from the magnitude for a significance level of $\mathrm{p}=0.05$ and calculated from the formula: (k-1) x (s-1) degrees of freedom. For gender, the number of degrees of freedom is 4 , for place of residence, age and education 12, while for average monthly net income 16. From the tables, the values of (2) were read, which, assuming a significance level of $\mathrm{p}=0.05$ and the degrees of freedom mentioned above, are respectively: $9.4877 ; 21.0261$ and 26.2962 . When the calculated values are greater than the critical values of the chi-squared distribution read from the tables, it is considered that there are grounds to reject $\mathrm{H}_{0}$ and accept the alternative hypothesis $\mathrm{H}_{1}$, which is marked in red.

Table 2

Chi squared independence test $(\chi 2)$

\begin{tabular}{|l|l|c|l|c|}
\hline \multicolumn{1}{|c|}{ before the pandemic } & $\boldsymbol{\chi}^{\mathbf{2}}$ & \multicolumn{1}{c|}{ during the pandemic } & $\chi^{\mathbf{2}}$ \\
\hline & $\begin{array}{l}\text { the relationship between the } \\
\text { gender of the respondents and } \\
\text { their opinion on payment and } \\
\text { data security when shopping } \\
\text { online }\end{array}$ & 2.3509 & $\begin{array}{l}\text { the relationship between the } \\
\text { gender of the respondents and } \\
\text { their opinion on payment and } \\
\text { data security when shopping } \\
\text { online }\end{array}$ & 2.7869 \\
\cline { 2 - 5 } & $\begin{array}{l}\text { the relationship of respondents' } \\
\text { gender to their opinion on: } \\
\text { "online shopping is a better } \\
\text { alternative to stationary } \\
\text { shopping" }\end{array}$ & 6.7414 & $\begin{array}{l}\text { the relationship of respondents' } \\
\text { gender to their opinion on: } \\
\text { "online shopping is a better } \\
\text { alternative to stationary } \\
\text { shopping" }\end{array}$ & 9.7052 \\
\hline $\begin{array}{l}\text { the relationship of respondents' } \\
\text { gender to their opinion on: } \\
\text { "further development of new } \\
\text { information and }\end{array}$ & 5.3325 & $\begin{array}{l}\text { the relationship of respondents' } \\
\text { gender to their opinion on: } \\
\text { "further development of new } \\
\text { information and }\end{array}$ & 10.6858 \\
\hline
\end{tabular}




\begin{tabular}{|c|c|c|c|c|}
\hline & $\begin{array}{l}\text { communication technologies is } \\
\text { necessary" }\end{array}$ & & $\begin{array}{l}\text { communication technologies is } \\
\text { necessary" }\end{array}$ & \\
\hline \multirow{3}{*}{ 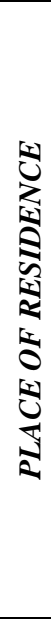 } & $\begin{array}{l}\text { the relationship between the } \\
\text { respondents' place of residence } \\
\text { and their opinion on payment } \\
\text { and data security when } \\
\text { shopping online }\end{array}$ & 17.9215 & $\begin{array}{l}\text { the relationship between the } \\
\text { respondents' place of residence } \\
\text { and their opinion on payment } \\
\text { and data security when } \\
\text { shopping online }\end{array}$ & 20.9524 \\
\hline & $\begin{array}{l}\text { the relationship of respondents' } \\
\text { place of residence to their } \\
\text { opinion on: "online shopping is } \\
\text { a better alternative to } \\
\text { stationary shopping" }\end{array}$ & 9.6896 & $\begin{array}{l}\text { the relationship of respondents' } \\
\text { place of residence to their } \\
\text { opinion on: "online shopping } \\
\text { is a better alternative to } \\
\text { stationary shopping" }\end{array}$ & 12.7989 \\
\hline & $\begin{array}{l}\text { the relationship of respondents' } \\
\text { place of residence to their } \\
\text { opinion on: "further } \\
\text { development of new } \\
\text { information and } \\
\text { communication technologies is } \\
\text { necessary". }\end{array}$ & 11.3313 & $\begin{array}{l}\text { the relationship of respondents' } \\
\text { place of residence to their } \\
\text { opinion on: "further } \\
\text { development of new } \\
\text { information and } \\
\text { communication technologies is } \\
\text { necessary". }\end{array}$ & 11.7771 \\
\hline \multirow{3}{*}{ త্ত } & $\begin{array}{l}\text { the relationship between the } \\
\text { respondents' age and their } \\
\text { opinion on payment and data } \\
\text { security when shopping online } \\
\text { and data security }\end{array}$ & 12.8438 & $\begin{array}{l}\text { the relationship between the } \\
\text { respondents' age and their } \\
\text { opinion on payment and data } \\
\text { security when shopping online } \\
\text { and data security }\end{array}$ & 8.8060 \\
\hline & $\begin{array}{l}\text { the relationship of respondents' } \\
\text { age to their opinion on: "online } \\
\text { shopping is a better alternative } \\
\text { to stationary shopping" }\end{array}$ & 17.3023 & $\begin{array}{l}\text { the relationship of respondents' } \\
\text { age to their opinion on: "online } \\
\text { shopping is a better alternative } \\
\text { to stationary shopping" }\end{array}$ & 10.9527 \\
\hline & $\begin{array}{l}\text { the relationship between the } \\
\text { age of the respondents and } \\
\text { their opinion on: "further } \\
\text { development of new } \\
\text { information and } \\
\text { communication technologies is } \\
\text { necessary". }\end{array}$ & 23.2904 & $\begin{array}{l}\text { the relationship between the } \\
\text { age of the respondents and } \\
\text { their opinion on: "further } \\
\text { development of new } \\
\text { information and } \\
\text { communication technologies is } \\
\text { necessary". }\end{array}$ & 15.5086 \\
\hline \multirow{3}{*}{ 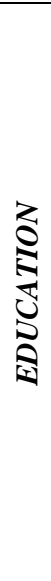 } & $\begin{array}{l}\text { relationship between } \\
\text { respondents' education and } \\
\text { their opinion on payment and } \\
\text { data security during online } \\
\text { shopping }\end{array}$ & 46.6269 & $\begin{array}{l}\text { relationship between } \\
\text { respondents' education and } \\
\text { their opinion on payment and } \\
\text { data security during online } \\
\text { shopping }\end{array}$ & 33.3440 \\
\hline & $\begin{array}{l}\text { relationship of respondents' } \\
\text { education to their opinion on: } \\
\text { "online shopping is a better } \\
\text { alternative to stationary } \\
\text { shopping" }\end{array}$ & 54.8109 & $\begin{array}{l}\text { relationship of respondents' } \\
\text { education to their opinion on: } \\
\text { "online shopping is a better } \\
\text { alternative to stationary } \\
\text { shopping" }\end{array}$ & 57.0211 \\
\hline & $\begin{array}{l}\text { relationship of respondents' } \\
\text { education to their opinion on: } \\
\text { "further development of new } \\
\text { information and } \\
\text { communication technologies is } \\
\text { necessary". }\end{array}$ & 34.2802 & $\begin{array}{l}\text { relationship of respondents' } \\
\text { education to their opinion on: } \\
\text { "further development of new } \\
\text { information and } \\
\text { communication technologies is } \\
\text { necessary". }\end{array}$ & 35.6190 \\
\hline
\end{tabular}




\begin{tabular}{|c|c|c|c|c|}
\hline & $\begin{array}{l}\text { the relationship between the } \\
\text { respondents' average monthly } \\
\text { net income and their opinion } \\
\text { on payment and data security } \\
\text { while shopping online }\end{array}$ & 16.5753 & $\begin{array}{l}\text { the relationship between the } \\
\text { respondents' average monthly } \\
\text { net income and their opinion } \\
\text { on payment and data security } \\
\text { while shopping online }\end{array}$ & 11.2201 \\
\hline 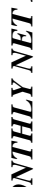 & $\begin{array}{l}\text { the relationship of respondents' } \\
\text { average monthly net income to } \\
\text { their opinion on: "online } \\
\text { shopping is a better alternative } \\
\text { to stationary shopping" }\end{array}$ & 17.6212 & $\begin{array}{l}\text { the relationship of respondents' } \\
\text { average monthly net income to } \\
\text { their opinion on: "online } \\
\text { shopping is a better alternative } \\
\text { to stationary shopping" }\end{array}$ & 17.0949 \\
\hline 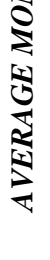 & $\begin{array}{l}\text { the relationship of respondents' } \\
\text { average monthly net income to } \\
\text { their opinion on: "further } \\
\text { development of new } \\
\text { information and } \\
\text { communication technologies is } \\
\text { necessary" }\end{array}$ & 15.2550 & $\begin{array}{l}\text { the relationship of respondents' } \\
\text { average monthly net income to } \\
\text { their opinion on: "further } \\
\text { development of new } \\
\text { information and } \\
\text { communication technologies is } \\
\text { necessary" }\end{array}$ & 18.8656 \\
\hline
\end{tabular}

Source: own research

It is therefore evident that in nine cases there are grounds to reject $\mathrm{H}_{0}$ and accept the hypothesis $\mathrm{H}_{1}$, which means that the analyzed variables show stochastic relationships. Respondents' opinions on: payment and data security during online shopping, online shopping as a better alternative to stationary shopping, and the need for further development of new information and communication technologies, are statistically significantly dependent on their level of education. This relationship is evident both before and during the pandemic. Better educated people saw, regardless of the pandemic, a greater need and necessity for the development of new information and communication technologies, tend to agree or strongly agree, with the statement that online shopping is a better alternative to stationary shopping, and consider online payments and data to be secure.

A statistical relationship was also noted between the age of the respondents and their opinions on the need for further development of new information and communication technologies before the pandemic. Before the outbreak of the pandemic, the largest number of respondents, $63.64 \%$ of the total group over 55 years of age tended to agree with the above statement. During the pandemic this relationship is not observed due to the fact that the majority of respondents, as many as $50.34 \%$ of all respondents strongly agree or rather agree with the need for further development of new technologies. Before the pandemic, the number of people agreeing with this statement reached only $42.86 \%$ of the total research sample.

The test conducted showed that there was a statistically significant relationship between the gender of the respondents and their opinions on: "online shopping is a better alternative to stationary shopping" and between the gender of the respondents and their opinions on: "further development of new information and communication technologies is necessary" during the pandemic. Before the pandemic, the responses of respondents, regardless of gender, showed significant discrepancies, while 
during the pandemic, the majority of women, $63.86 \%$ of all female respondents strongly agree or tend to agree that online shopping is a better alternative to stationary shopping, as well as $59.04 \%$ strongly agree or tend to agree with the need for further development of new information and communication technologies.

The test conducted showed that there was a statistically significant relationship between the gender of the respondents and their opinions on: "online shopping is a better alternative to stationary shopping" and between the gender of the respondents and their opinions on: "further development of new information and communication technologies is necessary" during the pandemic. Before the pandemic, the responses of respondents, regardless of gender, showed significant discrepancies, while during the pandemic, the majority of women, $63.86 \%$ of all female respondents strongly agree or tend to agree that online shopping is a better alternative to stationary shopping, as well as 59.04\% strongly agree or tend to agree with the need for further development of new information and communication technologies.

\section{Conclusions}

Management of economic activity within the conditions of an epidemiological crisis, in many countries, determined the change of attitude of customers for the way of purchasing goods and services.

Despite the negative impact of the COVID-19 pandemic on most sectors of the economy and the social sphere, there was a positive impact on the e-commerce market, whose revenues in Poland in 2020 amounted to about 100 billion PLN. In the coming years, further expansion of this market can be expected compared to traditional stationary shopping [48].

The pandemic helped to reduce the percentage of people who were technologically excluded, in terms of Internet access. During the pandemic, about $10 \%$ of respondents did not have permanent access to the Internet. The pandemic also had a positive effect on access to personal electronic equipment, which was declared by $80 \%$ of respondents in the discussed group. The Wilcoxon rank-sum test and the chi-squared test of independence confirm that the COVID-19 pandemic influenced statistically significant differences in the distribution of variables in the area of consumer behavior in the group of respondents over 45 years old in the e-commerce market.

The aim of the study was to assess consumer behavior and motivation before and during the pandemic. The conducted literature review highlighted the fact that the pandemic had an impact on the behavior of consumers, who more frequently and willingly buy via the Internet. On the basis of the Wilcoxon signed-rank test, it was determined that COVID-19 had a statistically significant impact on the opinions of respondents on cybersecurity, unlimited availability of the products offered and the need for further improvement of current technologies. The chi-square independence test showed a correlation during the pandemic, between the gender of the respondents and their opinions on online shopping, as a better alternative to brick- 
and-mortar shopping and that between the gender and the opinions of respondents, that further development of new information and communication technologies is necessary.

The conducted research was of a pilot nature. Further research should take into account larger sample sizes.

\section{Conflicts of Interest}

The authors declare no conflict of interest.

\section{References}

[1] Drucker, P. F.: Technology, management and society. PAN Book Ltd., London 1970, pp. 45-46

[2] Drucker, P. F.: Management and the World's Work, [in:] Bowerm J. (ed.), The Craft of General Management, Harvard Business School, Boston, 1991, pp. 57-59

[3] Raymonda, L.; Bergeronb, F.: Project management information systems: An empirical study of their impact on project managers and project success, International Journal of Project Management, Vol. 26, Issue 2, 2008, pp. 213220

[4] Koontz, H.; Weihrich, H.: Essentials of Management, McGraw-Hill, New York, 1990, p. 20

[5] Hitt, M. A.; Black, J. S.; Porter L. W.: Management, $3^{\text {rd }}$ Edition, New Jersey, Pearson, 2012, pp. 2-20

[6] Mintzberg, H.: The Manager's Job: Folklore and Fact, Harvard Business Review, July-August, 1975

[7] Krzakiewicz, K.: Corporate crisis management, Management, Vol. 9, No. 1, Uniwersytet Zielonogórski, Zielona Góra, 2005, pp. 15-22

[8] Huczek, M.: Organization culture a company crisis, Zeszyty Naukowe Wyższej Szkoły Humanitas w Sosnowcu, Zarządzanie, 2014, No. 2, pp. 3346

[9] Pearson, Ch. M.; Misra, S. K.; Clair, J. A.; Mitroff, I. I.: Managing The Unthinkable, Organizational Dynamics, 1997, 26 (2), pp. 51-64

[10] Pollard, D.; Hotho, S.: Crises, scenarios and the strategic management proces, Management Decision, 2006, 44(6), pp. $72-73$

[11] Lee, J.; Jares, S. M.; Heath, R. L.: Decision-Making Encroachment and Cooperative Relationships Between Public Relations and Legal Counselors in the Management of Organizational Crisis, Journal Of Public Relations Research, 1999, 11(3), p. 244 
[12] Boin, A.: The new world of crises and crisis management: implications for policymaking and research, Review of Policy Research, 2009 (26) pp. 367368

[13] Rerup, C.: Attentional Triangulation: Learning from Unexpected Rare Crises, Organization Science, 2009, 20(5) pp. 876-893

[14] Hargins, M.; Watt, J. D.: Organizational Perception Management, A framework to Overcome Crisis Events, Organization Development Journal, Spring, 2010, 27, 1, p. 74

[15] Dziegieć, J.: E-commerce, [in:] Królewski, J., Sala, P. (eds.), E-marketing. Modern trends, PWN, Warsaw, 2014, p. 231

[16] Thao Mai, P.; Tick, A.: Cyber Security Awareness and Behavior of Youth in Smartphone Usage: A Comparative Study between University Students in Hungary and Vietnam, Acta Polytechnica Hungarica, 2021, Vol. 18, No. 8, pp. 67-89

[17] Singhal, R.; Mittal, R.; Agarwal, S.: Development of E-Commerce in Developing Countries (I.T. - Management), International Journal Of Management \& Behavioural Sciences (IJMBS), 2013, Vol. 4, pp. 34-35

[18] Bartczak, K.: Bariery rozwojowe handlu elektronicznego, Exante, Wrocław, 2016, p. 35

[19] Lewicki, M.: Instrumenty tworzenia wartości dla klienta w handlu elektronicznym, Rozprawa Doktorska, Wydział Zarządzania Uniwersytetu Ekonomicznego, Poznań 2012, p. 15

[20] https://stat.gov.pl/metainformacje/slownik-pojec/pojecia-stosowane-wstatystyce-publicznej/1778,pojecie.html (access date on 28.09.2021)

[21] Mirescu, S.; Maiorescu, T.: The Premises and The Evolution Of Electronic Commerce, Journal of Knowledge Management, Economics and Information Technology, Scientific Papers.org, 2010, Vol. 1(1), pp. 1-12

[22] Ezenwoke, A.; Misra, S.; Adigun, M.: An Approach for e-Commerce OnDemand Service-oriented Product line Development, Acta Polytechnica Hungarica, 2013, Vol. 10, No. 2, pp. 69-87

[23] OECD: Protecting and Empowering Consumers in the Purchase of Digital Content Products, OECD Digital Economy Papers, 2013, No. 219, OECD Publishing, Paris (access date on 28.09.2021)

[24] Gibbs, J.; Kraemer, L.K.; Dedrick, J.: Environment and Policy Factors Shaping Global E-Commerce Diffusion: A Cross-Country Comparison, The Information Society California, 2003, p. 4

[25] WTO.: E-commerce in developing countries. Opportunities and challenges for small and medium-sized enterprises. 2013, https://www.wto.org/english/ res_e/ booksp_e/ecom_brochure_e.pdf, (access date on 14.09.2021) 
[26] Stefko, R.; Dorcak, P.; Pollak. F.: Shopping on the Internet from the point of view of customers, PolishJournal of Management Studies, Faculty of Management of Czestochowa University of Technology, 2011, No. 4, pp. 214-222

[27] Konopielko, Ł.; Wołoszyn, M.; Wytrębowicz, J.: Handel elektroniczny, Ewolucja i perspektywy, Exante, Wrocław, 2016, pp. 9-59

[28] Nanehkaran, A. Y.: An introduction to Electronic Commerce. International Journal Of Scientific\& Technology Research 2013, 2 (4), pp. 190-191

[29] Kowalik, S.: Zachowania konsumenckie - teoria preferencji - reklama, Ruch Prawniczy, Ekonomiczny I Socjologiczny, LVI, 2, Poznań, 1994, pp. 97-111

[30] Ostrowska, I.: Uwarunkowania zachowań nabywców w procesie zakupu, [in:] L. Gracz; I. Ostrowska, Młodzi nabywcy na zakupach, PLACET, Warsaw, 2014, pp. 11-35

[31] Witek, J.: Zachowania konsumentów - wyzwaniem rynku, [in:] Perenc, J.; Rosa, G. (eds.), Zachowania nabywców, WN US, Szczecin 2011, p. 11

[32] Karczewska, M., Determinanty zachowań konsumentów na rynku, Materiały V Krakowskiej Konferencji Młodych Uczonych, Sympozja i Konferencje KKMU, No 5, Kraków 2010, pp. 475-484

[33] Mowen, J. C.: Consumer Behavior, Macmillan, New York-London, 1987, p. 5

[34] Schiffman, L. G.; Kanuk, L. L.: Consumer Behavior, Pearson Prentice Hall, Englewood Cliffs 2000, pp. 5-6

[35] Michałowska, M.: Zachowania konsumentów na rynku artykułów żywnościowych i nieżywnościowych, Zeszyty Naukowe Uniwersytetu Szczecińskiego, Ekonomiczne Problemy Usług, 2010, 54, No. 549, pp. 6776

[36] Raczyńska, M.; Wiśniewski, A.: Zachowania zakupowe e-konsumentów, Konsumpcja i Rozwój, 2014, 3(8), pp. 48-60

[37] Rudnicki, L.: Zachowania rynkowe nabywców. Mechanizmy i uwarunkowania, Akademia Ekonomiczna w Krakowie, Kraków, 2004, p. 50

[38] Taher, G.: E-Commerce: Advantages and Limitations. International Journal of Academic Research in Accounting Finance and Management Sciences, January, 2021, 11(1), pp. 153-165

[39] Kolny, B.: Zachowania e-konsumentów przed zakupami w Internecie, Studia i Materiały, 2011, No. 51, pp. 17-26

[40] Rybkowska, A.: Zachowania zakupowe klientów sklepów internetowych, Zeszyty Naukowe Akademii Morskiej w Gdyni, Gdynia, 2010, No. 65, pp. 23-29 
[41] Ali, B. J.: Impact of consumer animosity, boycott participation, boycott motivation, and product judgment on purchase readiness or aversion of Kurdish consumers in Iraq, J. Consum. Aff, 2021, 55, pp. 504-523

[42] Ślusarczyk, B.; Hajizada, S.; Kovalyova, I.; Sakhbieva A.; Impact of the COVID-19 Pandemic on Online Consumer Purchasing Behavior, Journal of Theoretical and Applied Electronic Commerce Research, 2021, 16, pp. 2263 2281

[43] Jílková, P.; Králová, P.: Digital consumer behavior and eCommerce trends during the COVID-19 crisis. Int. Adv. Econ. Res., 2021, 27, pp. 83-85

[44] OECD: E-commerce in the times of COVID-19, OECD Policy Responses to Coronavirus (COVID-19), 2020, https://read.oecd ilibrary.org/view/?ref=137_137212-t0fjgnerdb\&title=E-commerce-in-thetime-of-COVID-19\&_ga=2.9432245.1400116068.1638628242327042349.1638628240 (access date on 04.12.2021)

[45] Ciesielski, M.: E-Commerce i Fintechy. System naczyń połączonych, 2020, https://static.300gospodarka.pl/media/2020/11/Raport_-Ecommerce-ifintechy_System-naczy\%C5\%84-po\%C5\%82\%C4\%85czonych_2020-r.pdf (access date on 04.12.2021)

[46] GUS: Społeczeństwo informacyjne w Polsce w 2020 r.,https://stat.gov.pl/obszary-tematyczne/nauka-i-technika-spoleczenstwoinformacyjne/spoleczenstwo-informacyjne/spoleczenstwo-informacyjne-wpolsce-w-2020-roku, 1,14.html (access date on 27.09.2021)

[47] CBOS (2019) Korzystanie z Internetu, https://www.cbos.pl/SPISKOM.POL/ 2019/K_095_19.PDF?fbclid=IwAR3WZIKOFuP0rXb2z8oSiG4DqMPyycf ZhRsRfSNdOUVD685Dsf0_LvLRSqk (access date on 27.09.2021)

[48] https://businessinsider.com.pl/finanse/handel/rynek-e-commerce-w-polsceosiagnie-wartosc-162-mld-zl/8x90t02 (access date on 29.09.2021) 